\begin{tabular}{lr}
\hline Jurnal Abdimas llmiah & JURNAL ABDIMAS ILMIAH CITRA BAKTI \\
Citra Bakti & Volume 2, Nomor 2, November 2021 \\
$(\mathrm{JAICB})$ & \\
\hline
\end{tabular}

\title{
LAYANAN KONSELING PRANIKAH MELALUI PENDEKATAN PROBLEM BASED LEARNING BAGI REMAJA DI KALIMULYA DEPOK
}

\author{
Cindy Marisa'), Evi Fitriyanti' ${ }^{2)}$, Sri Utami ${ }^{3)}$ \\ ${ }^{1,2)}$ Bimbingan dan Konseling, Universitas Indraprasta PGRI \\ 1) cindymarisa13@gmail.com, ${ }^{2}$ ibukevifitriyanti.21@gmail.com, \\ ${ }^{3)}$ sriutami.unindra@gmail.com
}

\begin{abstract}
Histori artikel
Abstrak

Received:

21 September 2021

Pemahaman yang rendah tentang konsep pernikahan pada remaja dapat berdampak negatif bagi kehidupan pernikahan. Konsep pernikahan bila tidak dibingkai melalui arah yang seharusnya dapat

Accepted:

22 Oktober 2021

Published:

30 November 2021 membawa remaja pada masa depan yang penuh resiko dikarenakan minimnya informasi atau kelirunya menerima informasi tentang pernikahan. Terkait dengan hal tersebut, Layanan Konseling Pranikah menjadi salah satu langkah awal pembekalan remaja dalam memiliki konsep pernikahan yang akan membawanya pada bagaimana cara remaja mengarahkan dirinya dalam suatu hubungan pranikah kelak. Pendekatan Problem Based Learning yang diintergrasikan dengan layanan informasi ini dapat memberikan keluasan peserta layanan untuk mendapatkan sajian materi secara kontekstual dan mendorong partisipasi aktif dalam ber-BMB3 (Berpikir, Merasa, Bersikap, Bertindak, dan Bertanggung Jawab). Layanan lain yang menjadi muara dalam konseling pranikah ini yaitu Layanan Konsleing Perorangan. Pengabdian kepada Masyarakat ini, bermaksud memberikan pengetahuan dan wawasan tentang konsep pernikahan sehingga menjadi lebih luas dan realistis serta menjadi mampu mengarahkan dirinya pada perilaku positif dalam membina hubungan pranikah. Kegiatan ini melibatkan 52 peserta layanan di wilayah Depok melalui kegiatan tatap muka virtual. Hasil dari kegiatan ini adalah layanan informasi melalui pendekatan problem based learning dan konseling perorangan memberikan kontribusi positif terhadap peningkatan wawasan, pengetahuan, dan perilaku remaja terkait hubungan pranikah dan dapat menjadi alternatif bagi para praktisi konseling dalam upaya penguatan konsep pranikah.
\end{abstract}

Kata-kata Kunci: Konseling, Pranikah, Problem Based Learning 
Abstract. Low understanding of the concept of marriage in adolescents can have a negative impact on married life. The concept of marriage if it is not framed in a direction that should be able to bring teenagers into a future full of risks due to the lack of information or the wrong information about marriage. Related to this, the Premarital Information Service is one of the first steps in providing teenagers with the concept of marriage which will lead them to how teenagers direct themselves in a premarital relationship in the future. The Problem Based Learning approach which is integrated with this information service can provide service participants with a broad range of contextual presentations of material and encourage active participation in BMB3 (Thinking, Feeling, Behaving, Acting, and Responsible). Another service that becomes the estuary in this premarital counseling is the Individual Counseling Service. This Community Service aims to provide knowledge and insight into the concept of marriage so that it becomes wider and more realistic and is able to direct itself to positive behavior in fostering premarital relationships. This activity involved 52 service participants in the Depok area through virtual face-to-face activities. The result of this activity is that information services through a problembased learning approach and individual counseling make a positive contribution to increasing adolescent insight, knowledge, and behavior related to premarital relationships and can be an alternative for counseling practitioners in an effort to strengthen the premarital concept.

Keywords: Counseling, Premarital, Problem Based Learning.

\section{PENDAHULUAN}

Remaja diartikan sebagai usia muda/pemuda atau mulai dewasa, sudah sampai umur untuk kawin. Kurun masa remaja menurut pendapat ahli Havighurst adalah berada pada usia 12-18 tahun dan sejalan dengan definisinya, remaja memiliki tugas perkembangan untuk mencapai hubungan-hubungan yang baru dan lebih matang dengan teman sebaya antar jenis kelamin yang sama dan berbeda, mencapai peranan sosial sebagai pria dan wanita, menerima kesatuan tubuh sebagaimana adanya dan menggunakannya secara efektif, mencapai kemerdekaan emosional terhadap orangtua dan orang dewasa lainnya, mencapai keadaaan dimilikinya jaminan untuk kemerdekaan ekonomi, memilih dan mempersiapkan diri untuk suatu pekerjaan, mempersiapkan diri untuk pernikahan dan kehidupan berkeluarga, mengembangkan keterampilan intelektual dan konsep - konsep yang perlu untuk kehidupan sebagai warga negara, mengembangkan hasrat dan mencapai kemampuan bertingkah laku yang dapat dipertimbangkan secara sosial, menguasai seperangkat nilai dan sistem etika sebagai pedoman (Prayitno \& Amti, 2004).

Penjelasan tentang definisi dan tugas perkembangan remaja memberikan makna bahwa pada fase ini, remaja perlu memiliki kesiapan di dalam menjalani fase perkembangan yang berikutnya yaitu fase atau masa Dewasa. Salah satu aspek yang perlu disiapkan adalah berkenaan dengan upaya mempersiapkan diri untuk pernikahan dan kehidupan berkeluarga (Sari \& Sunarti, 2013). Sebagai bagian dari pemenuhan tugas perkembangannya, menjadi hal yang wajar jika remaja mulai memiliki ketertarikan dengan lawan jenis dan mulai memikirkan tentang pernikahan. Fase ini menjadi krusial dimana pada fase ini konsep tentang pernikahan mulai terbentuk. Oleh karena itu pendidikan tentang kehidupan berkeluarga, pergaulan, wawasan dan pengetahuan tentang pranikah menjadi bagian yang turut berperan dalam menentukan bagaimana remaja memiliki konsep tentang pernikahan (Aziz, Budiyanti, Pallah, \& Pandoe, 2021). 
Konsep pernikahan juga dapat terbentuk saat remaja mulai menjalankan tugasnya dalam mengidentifikasi peran lawan jenis, di masa ini remaja mulai memiliki ketertarikan dan memperhatikan lawan jenis yang tidak menutup kemungkinan berlanjut sampai kepada membina hubungan yang lebih serius yang mengacu pada hubungan pranikah (Umami, 2019). Dalam proses ini, pemahaman dan konsep yang rendah tentang pernikahan pada remaja dapat berdampak negatif bagi kehidupan pernikahan kelak. Selain itu, rasa ingin tahu yang besar pada setiap remaja bila tidak dibingkai melalui arah yang seharusnya dapat membawa remaja pada masa depan yang penuh resiko dikarenakan minimnya informasi atau kelirunya menerima informasi tentang pernikahan.

Informasi mengenai persiapan pernikahan dapat diberikan melalui kegiatan pendidikan pranikah dimana kata pranikah tersusun dari dua kata yaitu "pra" dan "nikah". Kata "pra" yang memberi makna "sebelum", sementara kata "nikah" diartikan sebagai ikatan (akad) perkawinan yang dilakukan sesuai dengan ketentuan hukum dan ajaran agama (Salmah, 2017). Berdasarkan definisi dari 2 (dua) kata tersebut dapat dipahami bahwa pendidikan pranikah merupakan sebuah proses atau upaya untuk memberikan perubahan atau transformasi pengetahuan, nilai-nilai serta keterampilan yang lebih baik mengenai pernikahan. Hal tersebut dilakukan sebelum pernikahan itu terjadi atau bahkan sebelum memiliki pasangan maupun sebelum mengambil keputusan dalam memilih calon pendamping. Pendidikan pranikah penting untuk dipelajari bagi remaja sebagai langkah awal membekali diri agar memiliki konsep pernikahan yang realistis, mampu mengarahkan diri ke arah perilaku yang positif dan konstruktif, serta memiliki kemampuan dalam menjalani lika-liku kehidupan pernikahan kelak (Qomaro, 2019).

Konsep-konsep yang perlu dipahami secara mendalam mengenai kesiapan menikah terdiri atas kesiapan emosi, sosial, peran, dan finansial (Wibowo, 2021). Selain itu, kesiapan religius terkait dengan pernikahan juga perlu menjadi perhatian penting untuk mewujudkan pernikahan yang bahagia (Fitriani \& Handayani, 2020). Berbagai aspek tersebut perlu diketahui, dipahami, dan dimaknai sejak remaja. Bimbingan dan Konseling sebagai pelayanan yang juga bekerja pada setting luar pendidikan (masyarakat) dapat memberikan pelayanan dalam kehidupan berkeluarga (Habsy, 2017). Konselor dapat turut mengambil peran dalam ranah Pemberdayaan Kesejahteraan Keluarga (PKK) dengan memberikan pelayanan BK berupa Layanan Informasi guna memberikan pemahaman dan sebagai upaya menghindarkan remaja dari kondisi negatif akibat dari ketidaktahuan atau kurangnya informasi tentang pranikah. Layanan Informasi merupakan salah satu jenis layanan dalam BK yang memiliki format fleksibel dimana bisa diberikan secara perorangan, kelompok, klasikal, lapangan, maupun dalam format jarak jauh (daring) (Prayitno, 2018)

Layanan informasi memiliki tujuan umum agar dikuasainya informasi tertentu oleh peserta layanan dimana informasi yang diperoleh tersebut selanjutnya digunakan oleh peserta 
untuk keperluan hidupnya sehari-hari dan perkembangan dirinya. Secara lebih khusus, tujuan layanan informasi terkait dengan fungsi konseling terutama pada fungsi pemahaman. Melalui pelaksanaan layanan informasi, dimungkinkan terwujudnya pengembangan kehidupan remaja dalam berbagai bidang diantaranya yang pertama adalah pengembangan kehidupan pribadi, yaitu bidang pelayanan BK yang membantu individu dalam memahami, menilai, dan mengembangkan potensi dan kecakapan, bakat dan minat, serta kondisi kehidupan yang berkarakter cerdas dan beragama sesuai dengan karakteristik pribadi dan kebutuhan dirinya secara realistik, yang kedua adalah pengembangan kehidupan sosial, yaitu bidang pelayanan BK yang membantu individu dalam memahami dan menilai serta mengembangkan kemampuan hubungan sosial yang sehat, efektif, dan berkarakter cerdas dengan teman sebaya, anggota keluarga, dan warga lingkungan sosial yang lebih luas,yang ketiga adalah pengembangan kemampuan Belajar, yaitu bidang pelayanan BK yang membantu individu mengembangkan kemampuan belajar sesuai program studi dan arah peminatannya, berdisiplin, ulet, dan optimal dalam rangka mengikuti pendidikan pada jenjang/jenis satuan pendidikannya, serta belajar secara mandiri, yang keempat adalah pengembangan Karir, yaitu bidang pelayanan BK yang membantu individu dalam menerima, memahami, menilai informasi dan pengalaman, serta memilih dan mengambil keputusan arah karir secara jelas, objektif, dan bijak (Prayitno, 2018). Bidang pengembangan yang dikembangkan dalam layanan informasi pranikah mengacu pada bidang pengembangan kehidupan pribadi yang berupaya mendorong setiap individu remaja memiliki pemahaman dan wawasan yang lebih mendalam tentang konsep pra pernikahan sehingga remaja dapat lebih mempersiapkan diri untuk mewujudkan kehidupan berkeluarga yang harmonis.

\section{METODE PELAKSANAAN}

Kegiatan pengabdian kepada masyarakat ini dilakukan dengan media tatap muka virtual dikarenakan lingkungan berada pada zona merah di masa Pandemi Covid-19. Pelaksanaan dikoordinasikan secara intensif dengan mitra melalui beberapa tahapan, antara lain

1. Tahap Persiapan

a. Tinjauan Lokasi

Tim pengusul melakukan kunjungan ke lokasi kegiatan sebagai bagian dari tahap persiapan sehingga tim dapat mengetahui kondisi lapangan yang akan menjadi tempat pelaksanaan kegiatan. Tinjauan lokasi dilakukan berulang kali untuk menjalin komunikasi interaktif terhadap mitra kegiatan.

b. Pengumpulan data/Observasi

Melalui metode pengumpulan data berupa observasi, tim bermaksud untuk mendapat informasi yang berhubungan dengan pelaksanaan kegiatan PkM ini agar tujuan yang akan 
dicapai dapat terpenuhi. Data tersebut diantaranya profil RW 11 Kalimulya Cilodong Depok sebagai mitra kegiatan PkM, kebutuhan masyarakat, sarana dan prasarana yang mendukung kegiatan PkM, dan kondisi remaja di Lingkungan Kalimulya Depok dalam melaksanakan kehidupan sehari-hari.

c. Studi Kepustakaan

Studi kepustakaan dilakukan dengan mencari referensi untuk kebutuhan teoritis tentang kegiatan PKM ini. Studi kepustakaan dilakukan dengan mencari referensi ilmiah yang sesuai kebutuhan kegiatan pengabdian masyarakat melalui search engine, dan memanfaatkan berbagai bahan bacaan yang dimiliki yang terkait dengan kebutuhan masyarakat mitra.

d. Analisis Kelengkapan

Pada tahap ini, tim melakukan analisis terhadap kebutuhan-kebutuhan yang dapat menunjang penerapan kegiatan PkM. Beberapa aspek analisis kelengkapan diantaranya lokasi, perlengkapan, peralatan penunjang, teknologi informasi, instrumen evaluasi serta ketersediaan personil yang ada di Kalimulya Depok.

\section{Tahap Pelaksanaan}

Penyelenggaraan pelaksanaan kegiatan, metode penyampaian materi secara jarak jauh dengan memanfaatkan media tatap muka virtual yaitu Google Meet. Informasi pranikah diberikan melalui pengkajian berbagai masalah yang sering terjadi dalam pernikahan beserta sebab dan sikap yang perlu dimiliki agar terhindar dari permasalahan tersebut. Pendekatan problem based learning ini dilakukan guna mendorong peserta menjadi lebih tertarik, menjadi lebih mudah paham dan termemori dengan baik sehingga berdampak pada pengarahan dirinya secara positif dalam membina hubungan pranikah. Permasalahan yang menjadi dasar pembahasan memberikan gambaran yang lebih mudah dipahami oleh peserta layanan. Adapun rincian kegiatan tersebut antara lain:

a. Memberikan link zoom kepada para peserta kegiatan.

b. Menunggu keseluruhan para peserta dapat masuk ke Google Meet.

c. Pengisian presensi kehadiran.

d. Pengisian Instrumen oleh para remaja yang mengikuti kegiatan PkM .

e. Penyampaian Layanan Informasi Pranikah melalui Pendekatan Problem Based Learning bagi Remaja di lingkungan Kalimulya Depok.

f. Menyimak bersama video yang diberikan pemateri kepada para remaja.

g. Diskusi dan tanya jawab terkait topik pranikah.

h. Pengumuman Door prizes bagi peserta aktif.

i. Penutupan dengan pemberian kesan dan pesan. 
j. Laiseg (Penilaian Segera) melalui pengisian instrumen yang dipandu oleh tim PkM, melalui analisis hasil instrumen akan diketahui sejauh mana peningkatan pemahaman para remaja di dalam menyerap informasi yang di berikan oleh Tim PkM dan juga sejauh mana perubahan-perubahan positif yang tampak pada para remaja melalui observasi yang dilakukan oleh Tim PkM.

3. Tahap Pasca-Pelaksanaan

Kegiatan pasca pelaksanaan pengabdian kepada masyarakat ini, antara lain adalah:

a. Evaluasi kegiatan. Pasca pelaksanaan, tim melakukan evaluasi terkait hal-hal yang perlu dikembangkan dan diperbaiki dalam pemberian layanan konseling pranikah, baik dari segi persiapan maupun pelaksanaan kegiatan.

b. Mengukur kriteria keberhasilan dari kagiatan PkM berdasarkan hasil laiseg.

c. Penyusunan laporan kegiatan. Laporan kegiatan perlu disusun secara sistematis sebagai bentuk dokumen telah dilaksanakannya kegiatan sebagaimana yang direncankan.

d. Persiapan diseminasi/publikasi. Diseminasi yang dilakukan dalam lingkup keilmuan Bimbingan dan Konseling perlu dipersiapkan sehingga hasil kegiatan dapat dipublikasikan kepada praktisi konseling baik secara lokal, nasional, maupun internasional sehingga dapat menjadi referensi pelayanan bagi klien di lingkungan masyarakat.

\section{HASIL DAN PEMBAHASAN}

\section{Hasil}

\section{Kesiapan Religius}

Kesiapan religius para peserta layanan terkait dengan penikahan dapat dilihat dalam diagramdiagram berikut. Gambar 2 menunjukkan bahwa remaja sudah memiliki konsep pernikahan yang bertujuan untuk meningkatkan nilai keimanan dan ketaqwaan kepada Tuhan YME. Remaja yang memiliki kesiapan dipersentasikan sebesar 92,3\%. Konsep pernikahan yang bertujuan membangun keluarga sakinah (tentram, damai, sejahtera juga dengan persentasi sangat tinggi yaitu 96,2\%. Dan remaja juga memiliki konsep pernikahan untuk menghindari diri dari perbuatan zina dengan persentase $78,8 \%$ dengan pilihan sesuai, sementara remaja yang merasa cukup sesuai berada pada persentase $15,4 \%$, dan $5,8 \%$ menyatakan kurang sesuai. 


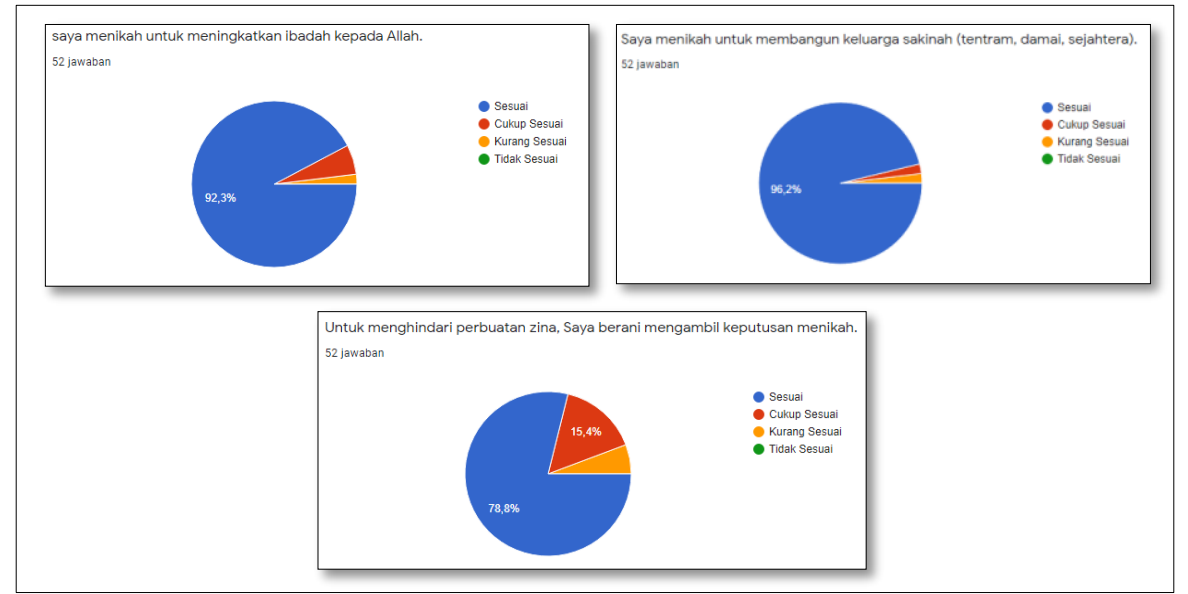

Gambar 2. Diagram Kesiapan Pernikahan dalam Nilai-nilai Religius

\section{Kesiapan Emosi}

Pernikahan yang berhasil juga memerlukan kesiapan emosi. Remaja perlu mempersiapkan emosi yang matang untuk membina sebuah pernikahan.

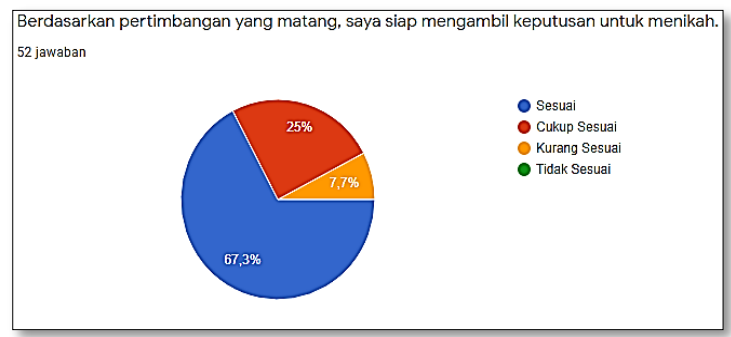

\section{Gambar 3. Diagram Kesiapan Emosi dalam Mempertimbangkan Pernikahan secara Matang}

Pada Gambar 3 remaja menyepakati bahwa dalam memutuskan untuk menikah diperlukan kesiapan emosi, kesesuaian terhadap konsep tersebut memperoleh persentase sebesar $67,3 \%$, sementara remaja yang merasa cukup sesuai berada pada $25 \%$, dan $7,7 \%$ lainnya merasa kurang sesuai.

\section{Kesiapan Sosial}

Lingkungan sosial juga perlu menjadi perhatian dalam kehidupan pernikahan, sehingga remaja perlu mempersiapkan diri dalam kematangan memiliki hubungan sosial sehingga pernikahan dalam berjalan dengan harmonis. Gambar 4 menunjukkan kematangan kesiapan hubungan sosial dengan keluarga pasangan dengan persentase sebesar $73,1 \%$ dalam menjalin kedekatan dengan keluarga pasangan, dan 98,1\% dalam menjalin hubungan baik secara umum. Lebih jauh, remaja juga mempersiapkan diri dengan meninjau latar belakang 
keluarga dengan kesesuaian sebesar $90.4 \%$ dan memahami karakter orangtua calon pasangan sebesar $96,1 \%$.

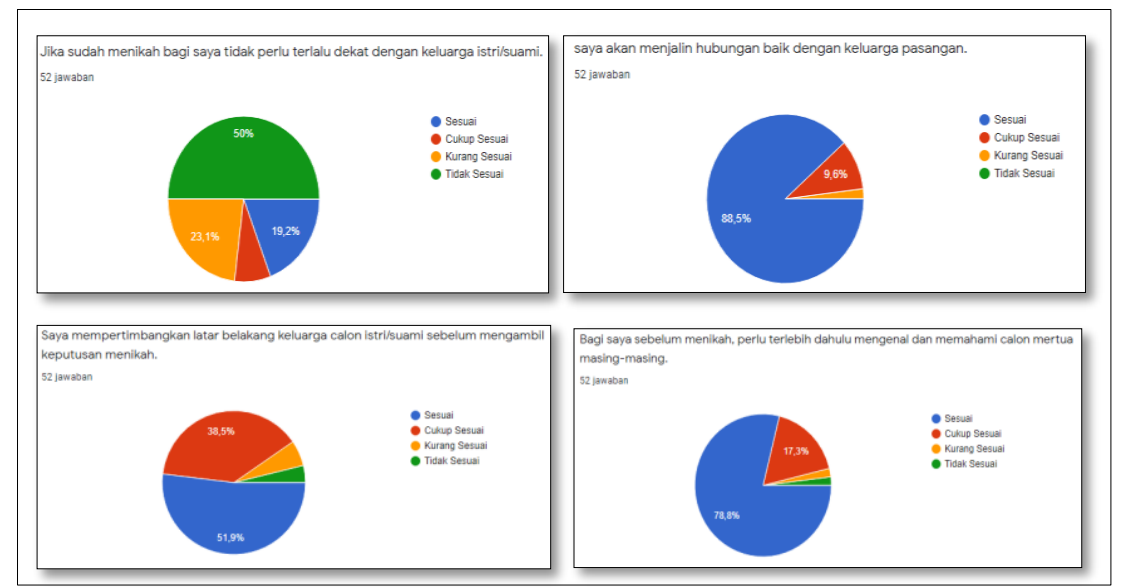

\section{Gambar 4. Diagram Kesiapan Sosial terhadap Keluarga Pasangan}

\section{Kesiapan Peran}

Pemahaman terkait peran suami dan istri juga perlu menjadi perhatian bagi pasangan yang akan menikah. Oleh karena itu, remaja perlu mempersiapkan dirinya dalam mengemban peran dalam sebuah pernikahan kelak. Persiapan tersebut terlihat dalam Gambar 5. Remaja merasa perlu mempersiapkan diri terkait peranan sebagai suami dan istri dalam pernikahan dengan membaca referensi pernikahan sebesar $84,6 \%$ dan $15,4 \%$ lainnya tidak melakuaknnya dengan membaca. Cara lain yang dilakukan remaja yaitu dengan mengikuti kegiatan ilmiah sebesar $84,6 \%$ dan 15,4\% lainya tidak melakukan diskusi ilmiah. Namun remaja juga memiliki kekhawatiran setelah memahami peranannya sebagai calon suami atau istri dengan persentase sebesar 34\% dan lainnya merasa lebih aman dan lebih antusias dengan persentase $66 \%$ dalam mempersiapkan dirinya untuk dapat menjadi suami atau istri yang ideal dalam rangka mewujudkan tujuan pernikahan yang sakinah (tentram, damai dan sejahtera).

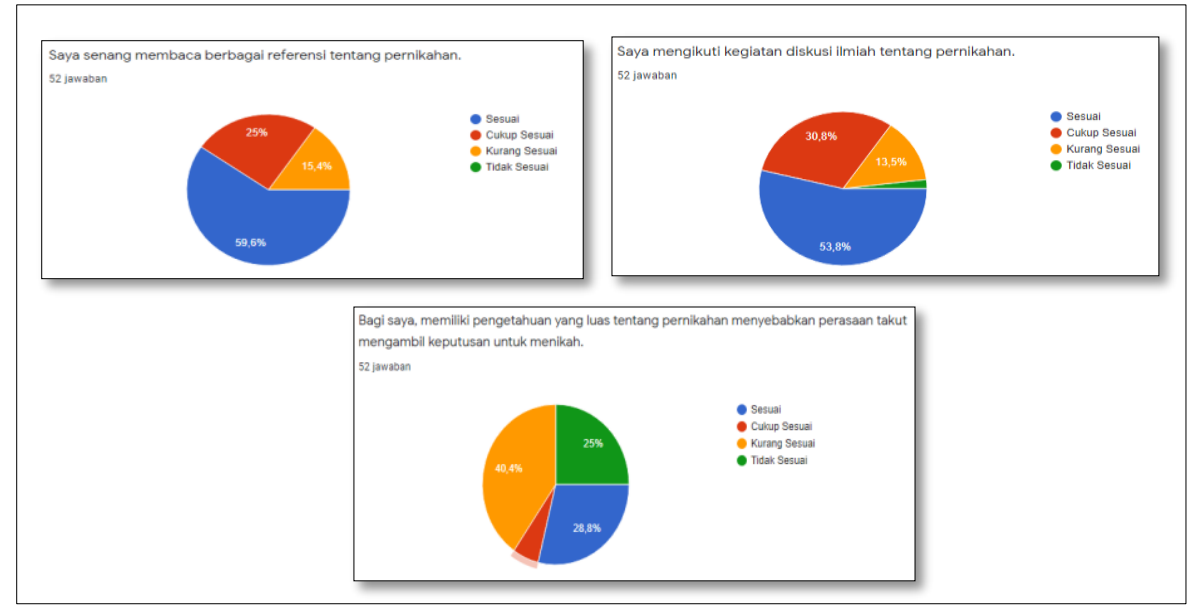

Gambar 5. Diagram Kesiapan Peran melalui Kajian IImiah 


\section{Kesiapan Finansial}

Kesiapan finansial juga menjadi hal yang sangat dibutuhkan untuk mewujudkan pernikahan yang bahagia. Kebutuan pokok untuk hidupa dan berkeluarga perlu dipenuhi dengan adanya kemampuan finansial. Gambar 6 menunjukkan pemahaman positif tentang konsep kematangan finansial bahwa ada 67,3\% remaja merasa khawatir dengan ketidakmapanan ekonomi untuk memenuhi kebutuhan dalam pernikahan. Dan ada 86,5\% remaja merencanakan kematangan finansial dengan serius sebelum memutuskan untuk hidup berkeluarga.

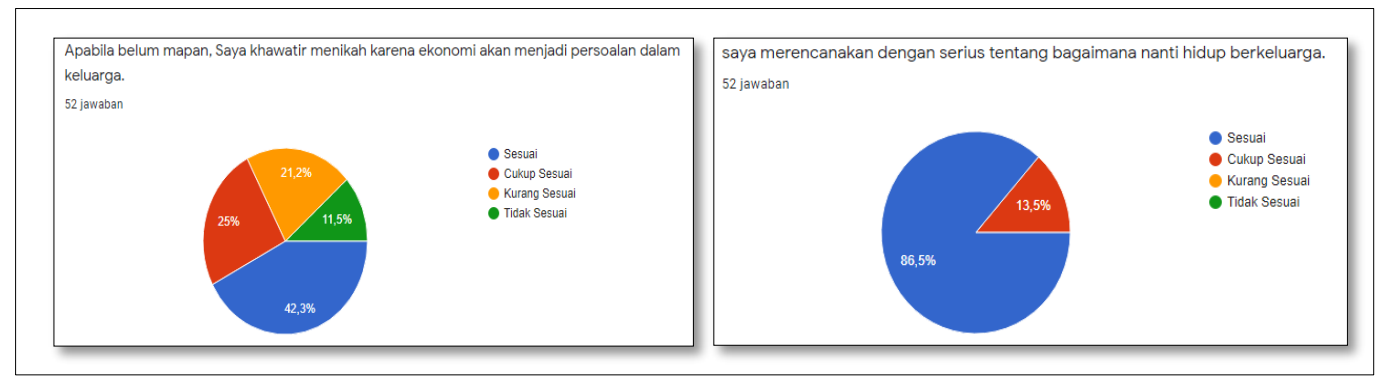

\section{Gambar 6. Diagram Kesiapan Peran melalui Kajian IImiah}

\section{Pembahasan}

Konsep pernikahan pada remaja seperti yang terpapar dalam hasil penelitian menunjukkan angka yang cukup baik. Remaja cukup memahami konsep kesiapan pernikahan mulai dari segi religius, emosi, sosial, peran dan finansial. Berbagai kesiapan tersebut dapat dijadikan dasar kesiapan remaja dalam membina rumah tangga yang berhasil dan bahagia. Kesiapan yang ditampilkan para responden remaja dalam kegiatan pengabdian kepada masyarakat yang dilaksanakan tim menggambarkan kondisi yang positif. Positif disini mengartikan bahwa persentase berada pada kategori baik.

Pertama, kesiapan religius responden ditunjukkan dengan konsep pernikahan sebagai ibadah sebesar 92,3\%, membangun keluarga sakinah (tentram, damai, sejahtera) 96,2\%, menghindari diri dari perbuatan zina dengan persentase $78,8 \%$ dengan pilihan sesuai, sementara remaja yang merasa cukup sesuai berada pada persentase 15,4\%, dan 5,8\% menyatakan kurang sesuai. Hal tersebut berarti remaja memiliki nilai keimanan dan ketaqwaan yang baik yang mendorong mereka untuk memiliki keputusan untuk menikah dengan tujuantujuan yang mulia, selain untuk meningkatkan nilai ibadah mereka juga menghindari perbuatan dosa (Zubaidillah \& Hasan, 2019).

Kedua, kesiapan emosi remaja memperoleh persentase sebesar $67,3 \%$, sementara remaja yang merasa cukup sesuai berada pada $25 \%$, dan $7,7 \%$ lainnya merasa kurang sesuai. 
Hal tersebut terukur dengan pernyataan remaja yang berpikir secara matang dalam memutuskan sebuah pernikahan. Remaja memahami, untuk melangkah ke jenjang pernikahan diperlukan kesiapan dan juga tanggung jawab sebagai suami atau istri, sehingga mereka mengontrol emosi dengan baik untuk melangkah kepada hubungan yang sakral dan tidak gegabah dalam melangsungkan pernikahan. Emosi yang matang dari kedua pasangan dalam membina rumah tangga membantu penyesuaian hubungan dan pengambilan keputusan secara bijaksana menuju kebahagiaan (Pattiruhu, 2019).

Ketiga, kesiapan sosial remaja menunjukkan kematangan kesiapan hubungan sosial dengan persentase sebesar $73,1 \%$ dalam menjalin kedekatan dengan keluarga pasangan, dan $98,1 \%$ dalam menjalin hubungan baik secara umum. Remaja juga mempersiapkan diri dengan meninjau latar belakang keluarga dengan kesesuaian sebesar $90.4 \%$ dan memahami karakter orangtua calon pasangan sebesar 96,1\%. Persentase tersebut menggambarkan bahwa remaja memahami bahwa dalam hubungan pernikahan, yang menikah bukanlah hanya dua orang melainkan dua keluarga, sehingga mereka merasa perlu memahami dan menjalin hubungan sosial yang baik dengan anggota keluarga istri/suami. Persentase tersebut menunjukkan skor positif mengenai kesiapan remaja dalam menjalin hubungan sosial dalam pernikahannya kelak. Hubungan sosial yang baik dalam keluarga meningkatkan kohesivitas dan kasih sayang dalam membina rumah tangga (Putriani, Daharnis, \& Ahmad, 2019).

Keempat, kesiapan remaja dalam pernikahan terkait peranannya sebagai suami dan istri dilakukan dengan membaca referensi pernikahan sebesar $84,6 \%$ dan mengikuti kegiatan ilmiah sebesar $84,6 \%$. Namun remaja juga memiliki kekhawatiran setelah memahami peranannya sebagai calon suami atau istri dengan persentase sebesar $34 \%$ dan lainnya merasa lebih aman dan lebih antusias dengan presentase $66 \%$ dalam mempersiapkan dirinya. Peran sebagai suami/istri perlu dipahami remaja secara tepat sehingga ketika menjadi suami/istri dapat menjalankan kewajiban dan mendapatkan hak sebagaimana mestinya yang lebih jauh berdampak pada terbangunnya keluarga yang sejahtera dan harmonis (Novianti, Sondakh, \& Rembang, 2017).

Terakhir, kesiapan finansial. Kesiapan ini dipahami dnegan baik oleh remaja dengan skor $67,3 \%$ remaja merasa khawatir dengan ketidakmapanan ekonomi untuk memenuhi kebutuhan dalam pernikahan. Dan ada $86,5 \%$ remaja merencanakan kematangan finansial dengan serius sebelum memutuskan untuk hidup berkeluarga. Finansial yang siap minimal dapat memenuhi kebutuhan rumah tangga yang menjadi kebutuhan pokok, seperti sandang, pangan, dan papan. Kebutuhan pokok yang tidak dapat terpenuhi sangat dekat dengan ketidakharmonisan dalam keluarga (Rizki, 2019; Sururie \& Yuniardi, 2018). Hal ini menjadi hal yang perlu menjadi persiapan penting bagi remaja dalam merencanakan pernikahan.

\section{KESIMPULAN}


Kegiatan pengabdian kepada masyarakat dengan tema layanan konseling pranikah dengan pendekatan problem based learning ini memberikan hasil yang positif terhadap remaja di wilayah Kalimulya Depok, antara lain:

1. Terkondisikannya kemampuan yang mumpuni dalam kesiapan diri menuju pernikahan melalui keterarahan tugas dan tanggung jawab di dalam kehidupan berumah tangga sebagai suami dan istri agar dapat menciptakan keluarga yang harmonis dan mampu menjalankan kehidupan efektif sehari-hari.

2. Bertambahnya (WPKNS) wawasan, pengetahuan, keterampilan, nilai, dan sikap yang dimiliki para remaja dalam :

a. Memahami pentingnya kesiapan diri sebelum memilih untuk melakukan pernikahan kelak.

b. Meningkatnya rasa mawas diri dalam upaya menghindari diri dari hubungan seksual sebelum menikah.

c. Memahami dan memperoleh pandangan lebih mendalam mengenai tanggung jawab sebagai pasangan suami dan istri, serta;

d. Memahami dan mendapatkan pandangan lebih luas mengenai peranan dan tugas dengan optimal sebagai orang tua kelak.

\section{DAFTAR PUSTAKA}

Aziz, A. A., Budiyanti, N., Pallah, P., \& Pandoe, P. (2021). Pengaruh Pemahaman Konsep Pernikahan Terhadap Persiapan Menikah Di Kalangan Mahasiswa. Jurnal Pasopati: Pengabdian Masyarakat Dan Inovasi Pengembangan Teknologi, 3(2). Tersedia di https://ejournal2.undip.ac.id/index.php/pasopati/article/view/8377/5526.

Fitriani, D. A., \& Handayani, A. (2020). Hubungan Antara Kematangan Emosi Dan Religiusitas Dengan Kesiapan Menikah Pada Mahasiswa Fakultas Psikologi Universitas Islam Sultan Agung Semarang. Prosiding Konferensi IImiah Mahasiswa Unissula (KIMU) Klaster Humanoira. Tresedia http://jurnal.unissula.ac.id/index.php/kimuhum/article/view/8140/3709.

Habsy, B. A. (2017). Filosofi ilmu bimbingan dan konseling Indonesia. JP (Jurnal Pendidikan): Teori Dan Praktik, 2(1), 1-11. DOI: http://dx.doi.org/10.26740/jp.v2n1.p1-11.

Novianti, R. D., Sondakh, M., \& Rembang, M. (2017). Komunikasi antarpribadi dalam menciptakan harmonisasi (suami dan istri) keluarga didesa Sagea Kabupaten Halmahera Tengah. Acta Diurna Komunikasi, 6(2). Tersedia di https://ejournal.unsrat.ac.id/index.php/actadiurnakomunikasi/article/view/16203/15707.

Pattiruhu, H. (2019). Kebahagian Pernikahan Ditinjau Dari Kematangan Emosi. Unika Soegijapranata Semarang. Tersedia di http://repository.unika.ac.id/id/eprint/21585.

Prayitno. (2018). Konseling Profesional yang Berhasil. Depok: RajaGrafindo Persada.

Prayitno, E. A., \& Amti, E. (2004). Dasar-Dasar Bimbingan dan Konseling. Jakarta: Rineka Cipta.

Putriani, L., Daharnis, D., \& Ahmad, R. (2019). Kesiapan menikah mahasiswa ditinjau dari jenis kelamin, latar belakang budaya dan sosial ekonomi. JPGI (Jurnal Penelitian Guru Indonesia), 4(2), 76-85. DOI : https://doi.org/10.29210/02243jpgi0005. 
Qomaro, G. W. (2019). Peneguhan Ketahanan Negara Melalui Penguatan Ketahanan Keluarga dan Pendidikan Pranikah: Telaah Modal Sosial Pesantren. In Proceedings of Annual Conference for Muslim Scholars (Vol. 3, pp. 313-326). Tersedia di http://proceedings.kopertais4.or.id/index.php/ancoms/article/view/244/247.

Rizki, P. (2019). Faktor Sosial Ekonomi Dan Tingkat Kesejahteraan Keluarga Janda Di Kota Padang. Universitas Andalas. Tersedia di http://scholar.unand.ac.id/id/eprint/77575.

Salmah, S. (2017). Pernikahan dini ditinjau dari sudut pandang sosial dan pendidikan. AlHiwar: Jurnal IImu Dan Teknik Dakwah, 4(6). Tersedia di http://jurnal.uinantasari.ac.id/index.php/alhiwar/article/view/1215/923.

Sari, F., \& Sunarti, E. (2013). Kesiapan menikah pada dewasa muda dan pengaruhnya terhadap usia menikah. Jurnal IImu Keluarga \& Konsumen, 6(3), 143-153. DOI: https://doi.org/10.24156/jikk.2013.6.3.143.

Sururie, R. W., \& Yuniardi, H. (2018). Perceraian Dalam Keluarga Muslim Di Jawa Barat. AlManahij: Jurnal Kajian Hukum Islam, 12(2), 263-280. Tersedia di http://ejournal.iainpurwokerto.ac.id/index.php/almanahij/article/view/1361.

Umami, I. (2019). Psikologi Remaja. Idea Press Yogyakarta.

Wibowo, A. (2021). Studi Kasus Pernikahan Dini pada Remaja. Counseling Milenial (CM), 2(2), 341-350. Tersedia http://scholar.ummetro.ac.id/index.php/konselor/article/view/1056/488.

Zubaidillah, M. H., \& Hasan, H. (2019). Motivasi Menikah Mahasiswa Sekolah Tinggi IImu Al Quran (STIQ) Amuntai. AI Qalam: Jurnal IImiah Keagamaan Dan Kemasyarakatan, 3(2), 293-309. Tersedia di https://www.jurnal.stiq-amuntai.ac.id/index.php/alqalam/article/view/179/122. 